\title{
Productive performance of lettuce at different amounts and times of decomposition of dry scarlet starglory ${ }^{1}$
}

\author{
Desempenho produtivo da alface em diferentes quantidades e tempos de \\ decomposição de jitirana seca
}

\author{
Silvia Bezerra de Góes ${ }^{2}$, Francisco Bezerra Neto ${ }^{3 *}$, Paulo César Ferreira Linhares ${ }^{3}$, Glêidson Bezerra de Góes ${ }^{3}$ e \\ Joserlan Nonato Moreira ${ }^{3}$
}

\begin{abstract}
The use of spontaneous species as green manure in the production of vegetables is slowly starting to produce satisfactory results. The purpose of the present study was to evaluate the productive performance of lettuce at different quantities and times of decomposition of dry scarlet starglory (Merremia aegyptia L.) incorporated into the soil. The present study was carried out from October to December 2006 in a vegetable garden of Plant Sciences Department of the Universidade Federal Rural do Semi-Árido (UFERSA), Mossoró-RN, Brazil. The experimental design was a randomized complete block with the treatments arranged in a factorial $4 \times 4+1$, with three replications. The treatments consisted of the combination of four dry scarlet starglory amounts incorporated into the soil $\left(2.6 ; 5.2 ; 7.8\right.$ and $10.4 \mathrm{t} \mathrm{ha}^{-1}$ of dry matter) with four different decomposition times $\left(0 ; 10 ; 20\right.$ and 30 days before transplanting of lettuce - DBT), plus one additional treatment $\left(80 \mathrm{t} \mathrm{ha}^{-1}\right.$ of cattle manure, a traditional treatment in the lettuce cropping). The lettuce cultivar grown was 'Babá de Verão'. The evaluated characteristics were: height and diameter of plants, number of leaves per plant, fresh and dry mass of the lettuce shoots. The incorporation of dry scarlet starglory into the soil influenced the productive performance of lettuce in a positive way, thereby showing promise for use as a green manure. The highest fresh mass amount of the lettuce $\left(15.33 \mathrm{t} \mathrm{ha}^{-1}\right)$ was obtained with the incorporation of $6.68 \mathrm{tha}^{-1}$ of dry scarlet starglory to the ground in time of 30 days before transplanting of the lettuce.
\end{abstract}

Key words - Lactuca sativa. Merremia aegyptia. green manuring.

\begin{abstract}
Resumo - O uso de espécies espontâneas como adubo verde na produção de hortaliças está começando a apresentar resultados satisfatórios. Assim, o objetivo do presente trabalho foi avaliar o desempenho produtivo da alface em função de diferentes quantidades e tempos de decomposição de jitirana seca (Merremia aegyptia L.) incorporadas ao solo. O presente trabalho foi realizado entre outubro e dezembro de 2006 na Horta Didática do Departamento de Ciências Vegetais da Universidade Federal Rural do Semi-Árido (UFERSA), Mossoró-RN, Brazil. O delineamento experimental foi em blocos completos casualizados com os tratamentos arranjados em esquema fatorial $4 \times 4+1$, com 3 repetições. Os tratamentos consistiram da combinação de quatro quantidades de jitirana seca incorporadas ao solo $\left(2,6 ; 5,2 ; 7,8\right.$ e 10,4 t ha $\left.{ }^{-1}\right)$ com quatro tempos de decomposição $(0 ; 10$; 20 e 30 dias antes do transplantio da alface) mais um tratamento adicional ( $80 \mathrm{t} \mathrm{ha}^{-1}$ de esterco bovino, tratamento tradicional usado no cultivo dessa hortaliça). A cultivar de alface cultivada foi a Babá de Verão. As características avaliadas foram: altura e diâmetro de plantas, número de folhas por planta, massa fresca e seca da parte aérea da alface. A incorporação da jitirana seca ao solo influenciou de forma positiva no desempenho produtivo da alface, mostrando-se promissora para ser utilizada como adubo. A maior quantidade de massa fresca da alface $\left(15,33 \mathrm{tha}^{-1}\right)$ foi obtida com a incorporação no solo de $6,68 \mathrm{tha} \mathrm{h}^{-1}$ de jitirana seca no tempo de decomposição de 30 dias antes do transplantio da alface.
\end{abstract}

Palavras-chave - Lactuca sativa. Merremia aegyptia. Adubação verde.

\footnotetext{
* Autor para correspondência

'Recebido para publicação em 09/07/2010; aprovado em 10/06/2011

Parte da Dissertação de Mestrado apresentada pelo primeiro autor no Programa Pós-Graduação em Agronomia/Fitotecnia, UFERSA

${ }^{2}$ Instituto Brasileiro do Meio Ambiente e dos Recursos Naturais Renováveis - IBAMA, Escritório Regional de Altamira-PA, Rua Coronel José Porfírio, s/n, São Sebastião, Altamira-PA, Brasil, 68.370-000, silvia.goes@hotmail.com

${ }^{3}$ Departamento de Ciências Vegetais/UFERSA, Mossoró-RN, Brasil, 59.625-900, bezerra@ufersa.edu.br, paulolinhares@ufersa.edu.br; gleidsongoes@yahoo.com.br; moreiragronomo@hotmail.com
} 


\section{Introduction}

The degradation progress of the productive capacity of soils associated with the proliferation of pests and diseases has increased interest in the use of practices that minimize the degradation processes of soils and prevention of new areas. According to Fontanetti (2003), green manuring stands out amongst these techniques, to promote physical improvements, chemical and biological of soil properties, besides having a great effect in controlling weeds, either by physical effects and/or allelopathic. The effects of green manuring are variable, depending on factors, such as the species used, the handling given to biomass, the time of planting and cutting of green manure, the residence time of wastes in the soil and the interaction amongst these factors (ALCÂNTARA et al., 2000).

Apart from legumes, other species have been studied for use as green manure, including grasses. Recently, studies using spontaneous plant species have started to emerge. However, these spontaneous species can promote the same effects of land cover, biomass production and nutrient cycling that introduced or cultivated species for green manure (FAVERO; JUCKSCH, 2000, LINHARES et al., 2009b, 2009d). For Klein e Amaral (1988), the alternative of economic use of these species is mainly based on the ease of reproduction as well as its minimum requirements for a rational cropping.

Studies on species used as green manure at conditions of northeast Brazil are still limited. However, it is necessary to conduct research in the search for plant species adapted to the region with the potential to contribute more effectively in the protection and regeneration of soil fertility. Amongst these species is the scarlet starglory (Merremia aegyptia L.), which belongs to the Convolvulaceae family (LINHARES et al., 2009a, 2009c, 2009e; OLIVEIRA et al., 2011).

Lettuce (Lactuca sativa L.) is a leafy vegetable grown with higher commercial value in Brazil, with about seventy-five commercial cultivars, of which about eighteen are national (LOPES, 2005). This vegetable has played an increasingly important role in the list of priority food products for families. Sales at supermarkets, until recently, served to attract consumers who ended up buying other goods (marketing strategy). Currently, the situation is changing due to new standard of life of people that increasingly has less time to prepare meals.

Another factor that contributes to the above mentioned change is the awareness of consumers concerning the quality of food that must be produced within certain technical standards (clean water, fewer pesticides, etc.) and pass by processes, such as cleaning, sanitizing, grading and standardization to meet the market requirements (production, packaging and nutritional value) (CAETANO et al., 2001).

In Rio Grande do Norte, the consumption of lettuce is low compared with other regions, although a part of the production does meet the domestic demand. In this state, the planting of this species is restricted to small areas, where its intensive cultivation, often provides imbalances in soil fertility, causing mineral deficiency and consequently low productivity (PORTO, 1999).

There is little information about the use of green fertilizers in agricultural production in the Rio Grande do Norte state. However, the main problems include the adequacy of the green manure for the cultivation of vegetables, which depends, amongst other factors, on the region, the ideal management depending on the vegetable in succession and the complementation need of soil fertility with the other organic fertilizers (FONTANETTI, 2003).

Thus, the purpose of the present study was to evaluate the productive performance of lettuce at different quantities and times of decomposition of dry scarlet starglory incorporated into the soil.

\section{Materials and methods}

The present study was conducted in the vegetable garden of the Plant Sciences Department of the Universidade Federal Rural do Semi-Árido (UFERSA), in Mossoró, RN, Brazil, from June to October 2006 , at $5^{\circ} 11^{\prime} \mathrm{S}, 37^{\circ} 20^{\prime} \mathrm{W}$ and $18 \mathrm{~m}$ of altitude. The climate of the region according to Thornthwaite is semi-arid, dry and very hot, with a dry season (June to January) and a rainfall season (February to May). During this research, the mean daytime temperature was $28.2{ }^{\circ} \mathrm{C}$, daily sunshine $12 \mathrm{~h}$ and $50 \%$ R.H. The soil was classified as Eutrophic YellowRed Ultisols. Samples were taken in the experimental area and mixed in order to obtain a composite sample, which was analyzed at the Laboratory of Chemistry and Fertility of Soils of the UFERSA. The following results were obtained: $\mathrm{pH}$ (soil:water ratio 1:2.5) 7.40 (alkaline soil); Ca $5.43 \mathrm{cmol}_{\mathrm{c}} \mathrm{dm}^{-3} ; \mathrm{Mg} 1.83 \mathrm{cmol}_{\mathrm{c}} \mathrm{dm}^{-3}$; $\mathrm{K} 0.42 \mathrm{cmol}_{\mathrm{c}} \mathrm{dm}^{-3} ; \mathrm{Na} 0.88 \mathrm{cmol}_{\mathrm{c}} \mathrm{dm}^{-3} ; \mathrm{Al} 0.00 \mathrm{cmol}_{\mathrm{c}}$ $\mathrm{dm}^{-3}$; P $2.12 \mathrm{mg} \mathrm{dm}{ }^{-3}$; $\mathrm{N} 0.65 \mathrm{~g} \mathrm{~kg}^{-1}$; $5.62 \mathrm{~g} \mathrm{~kg}^{-1}$ and $\mathrm{C} / \mathrm{N} 8.65$.

The experimental design was a randomized complete block with the treatments arranged in a factorial $4 \times 4+1$, with three replications. The treatments consisted of the combination of four amounts of dry scarlet starglory incorporated into the soil $\left(2.6 ; 5.2 ; 7.8\right.$ and $10.4 \mathrm{t} \mathrm{ha}^{-1}$ dry matter) with four times of decomposition $(0 ; 10 ; 20$ and 30 days before the transplanting of lettuce - DBT), plus an additional treatment $\left(80 \mathrm{t} \mathrm{ha}^{-1}\right.$ of cattle manure, a treatment 
traditionally used in the cultivation of lettuce). Each plot had a total area of $1.44 \mathrm{~m}^{2}(1.20 \mathrm{~m} \times 1.20 \mathrm{~m})$ containing 36 lettuce plants spaced of $0.20 \mathrm{~m} \times 0.20 \mathrm{~m}$. The harvest area of each plot was $0.80 \mathrm{~m}^{2}(1.00 \mathrm{~m} \times 0.80 \mathrm{~m})$ containing 16 lettuce plants.

The soil preparation consisted of a harrowing followed by the construction of beds done manually with a hoe. The incorporation of scarlet starglory in the different amounts in each plot was done manually every ten days. Initially, the scarlet starglory amount was incorporated into the soil concerning to the decomposition time of 30 days. Ten days after was done the incorporation of the amount in the time of decomposition of 20 days and ten days after was incorporated the amount of scarlet starglory corresponding to the time of 10 days. Finally, it was incorporated the amount concerning to the time of 0 days. In each plot of the control treatment was applied the amount of $80 \mathrm{t} \mathrm{ha}^{-1}$ of cattle manure thirty days before lettuce sowing. Irrigations were carried out daily in two shifts, during the times of scarlet starglory decomposition, in order to promote soil microbial activity in the decomposition process. On time zero, the lettuce seedlings were transplanted to each plot, at 21 days of sowing. The day after the transplanting of lettuce, soil samples were taken at 0-20 cm depth in each plot of the experiment. The scarlet starglory used in the present study was collected from an area adjacent to the experiment at the flowering stage on 17 May 2006, and dried and stored in raffia bags with $12 \%$ humidity until to the installation of the experiment on 19 September 2006.

The cultivar of lettuce grown in the present study was Babá de Verão, recommended for planting in the semiarid region of northeastern Brazil. It belongs to the looseleaf group, and has the following characteristics: large leaves, slightly wrinkled, color light green, and tolerance to early bolting (SAKAMA, 2002). Its vegetative stage varies from 45 to 70 days, depending on the time of planting or region.

The lettuce was sown on 18 October 2006, in plastic cups of $150 \mathrm{ml}$ containing Plantmax substrate. Three to five seeds were sown per cup, and then thinned out two times; the first eight days after emergence, leaving three seedlings per cup and the second fifteen days, leaving only one seedling per cup. The lettuce seedlings were grown under shading, using a shelter covered with nylon mesh white. The transplanting to each plot was carried out in the second week of November 2006, when the seedlings were twenty days after sowing.

The irrigations were performed daily by microsprinkling in two applications (morning and afternoon), providing an average water sheet of $8 \mathrm{~mm}$ day $^{-1}$. Manual weedings were done when necessary. No kind of a chemical fertilizer supplement was used.

The lettuce harvest was performed 48 days after sowing, when the plants reached the maximum vegetative growth. At the time of the harvest, the plant stems were cut close to the ground. The following lettuce characteristics were evaluated: plant height and diameter, number of leaves per plant, fresh (productivity) and dry mass of shoots.

A univariate analysis of variance for randomized complete block design with the treatments arranged in a factorial design was performed on each characteristic of the lettuce through of the software SISVAR 3.01 (FERREIRA, 2000). The procedure for adjustment of the response curve was performed using the software Table Curve (JANDEL SCIENTIFIC, 1991). The response functions were evaluated based on the following criteria: significance of the error mean square of regression (EMSReg), high coefficient of determination $\left(\mathrm{R}^{2}\right)$, and significance of regression parameters, using the t test at 0.05 . The t test was also used to compare the mean of the additional treatment with the maximum mean of the treatment originated from the factorial.

\section{Results and discussion}

There was no significant interaction between the amounts of dry scarlet starglory incorporated into the soil and their times of decomposition in the plant height of lettuce (FIG. 1A; FIG. 1B). However, a quadratic function and an upward curve were adjusted to the height of plants under the amounts of dry scarlet starglory and their times of decomposition, respectively. The plant height increased with increasing amounts of scarlet starglory until the maximum value of $21.14 \mathrm{~cm}$ in the amount of scarlet starglory incorporated of $7.52 \mathrm{t} \mathrm{ha}^{-1}$ was reached, and decreasing thereafter, until the maximum amount of $10.4 \mathrm{t} \mathrm{ha}^{-1}$ (FIG. 1A). With the increasing time of decomposition of scarlet starglory, an increase in the height of the plants was observed, with the maximum value of $20.63 \mathrm{~cm}$ obtained in the time 30 days of decomposition, corresponding to an increase of $13.4 \%$ over the time zero day (FIG. 1B).

Linhares et al. (2007) observed an increase in the height of the rocket plants in function of the amounts of scarlet starglory applied and their times of decomposition, registering the highest values in the amount of $13.0 \mathrm{t} \mathrm{ha}^{-1}$ and at the time of 20 days of the incorporation. According to these authors, the macronutrient contents of scarlet starglory were in the order of $2.62 \% \mathrm{~N}, 0.17 \% \mathrm{P}, 0.04 \%$ 

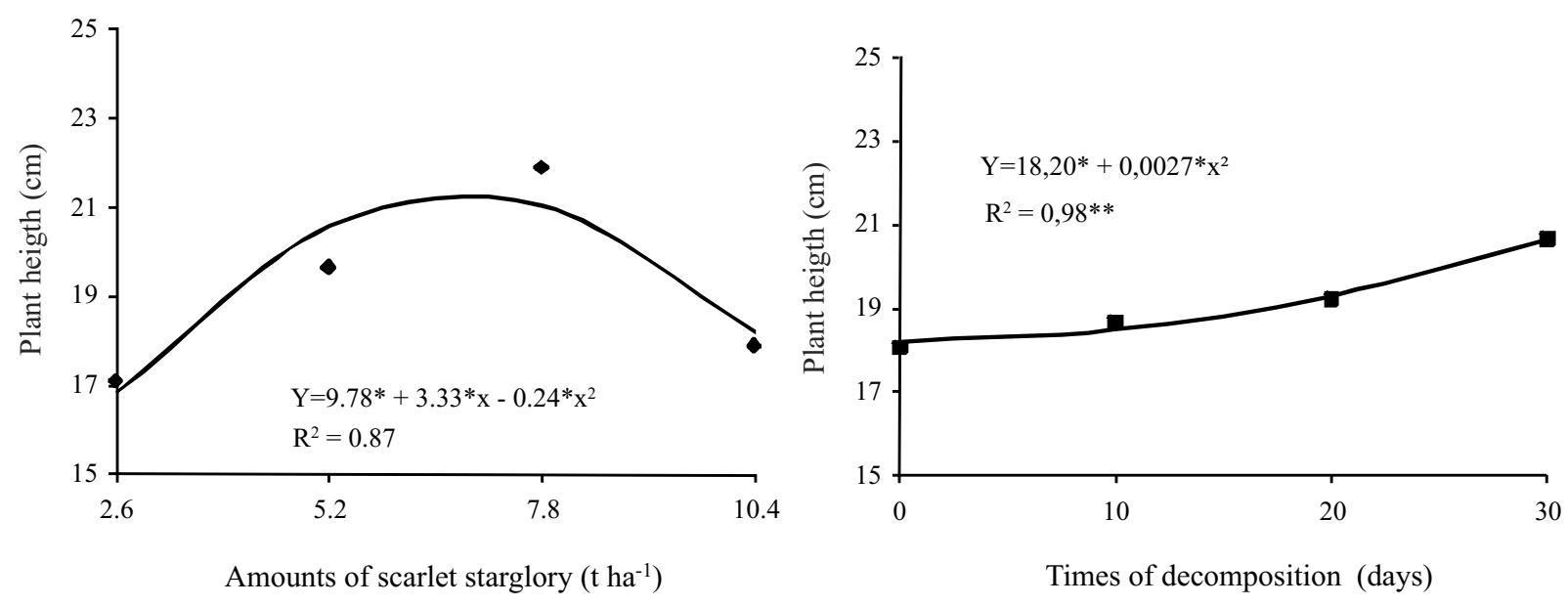

Significant at $\mathrm{p}<0.05$ by $\mathrm{t}$ test

Figure 1 - Plant height of lettuce under different amounts and times of decomposition of scarlet starglory

$\mathrm{K}$ and $1.95 \% \mathrm{Mg}$, respectively. Besides the nutrients available, the $\mathrm{C} / \mathrm{N}$ ratio of $19 / 1$ of this green manure was an important factor to promote the plant growth. The catering of $\mathrm{N}$ in adequate concentration favors vegetative growth; the photosynthetic active area expands and increases the productive potential of the crop because $\mathrm{N}$ plays a fundamental role in the growth and yield of the harvested products from leafy vegetables. An adequate supply of $\mathrm{N}$ is associated with high photosynthetic activity and the vigorous vegetative growth (FILGUEIRA, 2000). In lettuce, high doses of $\mathrm{N}$ provided a greater fresh weight and higher accumulation of nutrients in the leaves regardless of the source (ALVARENGA et al., 2000).

A significant interaction between the amounts of dry scarlet starglory incorporated into the soil and their decomposition times was observed on the diameter of the lettuce plants and number of leaves per plant (FIG. 2A; FIG. 2B). A linear function upward and a quadratic function were adjusted for the diameter of plants in function of the amounts of dry scarlet starglory applied within each time of decomposition. Partitioning this interaction, an increase in the diameter of plants with increasing amounts of scarlet starglory incorporated was observed at the time zero days, with the maximum value of $22.92 \mathrm{~cm}$ obtained in the amount of $10.4 \mathrm{t} \mathrm{ha}^{-1}$, corresponding to an increase of $36.2 \%$ in relation to a less amount applied of scarlet starglory of $2.6 \mathrm{t} \mathrm{ha}^{-1}$ (FIG. 2A). For times of 10; 20 and 30 days of decomposition, the diameter of plants increased with an increasing amount of scarlet starglory until the maximum values of 20.15, 24.69 and
$25.42 \mathrm{~cm}$, corresponding to the following amounts of dry scarlet starglory incorporated into the soil of 4.96 , 7.00 and $6.36 \mathrm{tha}^{-1}$, and decreasing thereafter until the maximum amount of scarlet starglory was incorporated (FIG. 2A). Castilhos et al. (2007) observed an increase of $11 \%$ in the diameter of lettuce using fertilization with the vermicompost of pig and horse as compared to mineral fertilization.

A quadratic function and an exponential were adjusted for the number of leaves per plant under the different amounts of dry scarlet starglory applied within each time of decomposition (FIG. 2B). For times of 0; 10 and 20 days of decomposition, the number of leaves per plant increased with an increasing amount of scarlet starglory until the maximum values of $34.8,35.5$ and 39.3 , corresponding to the following amounts of scarlet starglory incorporated of 5.13, 6.54 and $5.92 \mathrm{t} \mathrm{ha}^{-1}$, and decreasing thereafter until the maximum amount of green manure was incorporated (FIG. 2B). For the time of 30 days of decomposition, there was stability in the number of leaves per plant of lettuce of around 33, between the amounts of scarlet starglory applied of 2.6 and $7.8 \mathrm{t} \mathrm{ha}^{-1}$. However, there was a small increase in the number of leaves (6) from the amount of $7.8 \mathrm{t} \mathrm{ha}^{-1}$ until the highest amount was incorporated $\left(10.4 \mathrm{t} \mathrm{ha}^{-1}\right)$, reaching a value of 39 leaves per plant of lettuce.

For the fresh and dry mass of lettuce shoots, there was no significant interaction between the amounts of dry scarlet starglory incorporated into the soil and their times of decomposition (FIG. 3A; FIG. 3D). However, a quadratic function was adjusted for fresh and dry mass of shoots (FIG. 3A; FIG. 3C). An increase in both the masses 


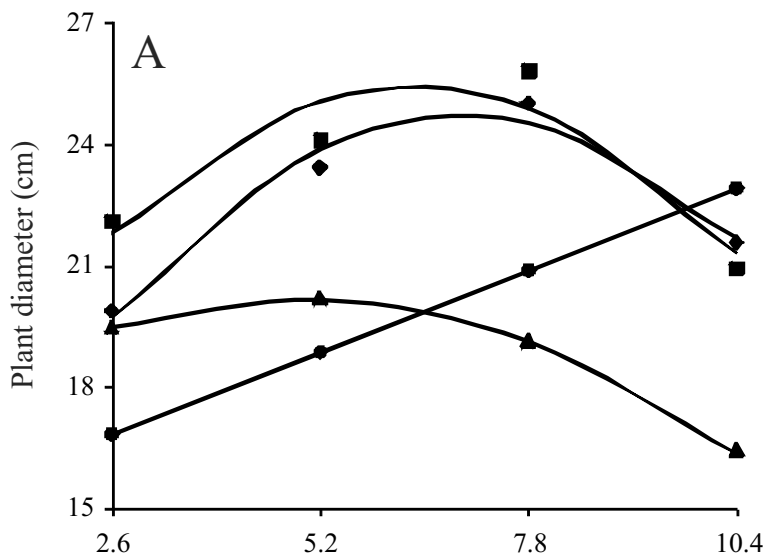

Amounts of scarlet starglory $\left(\mathrm{t} \mathrm{ha}^{-1}\right)$

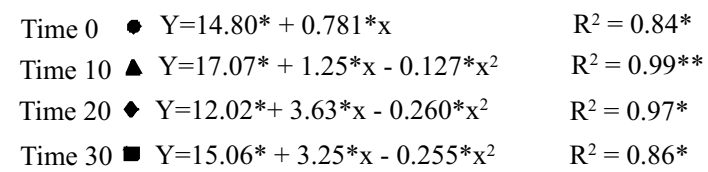

"Significant at $\mathrm{p}<0.05$ by $\mathrm{t}$ test

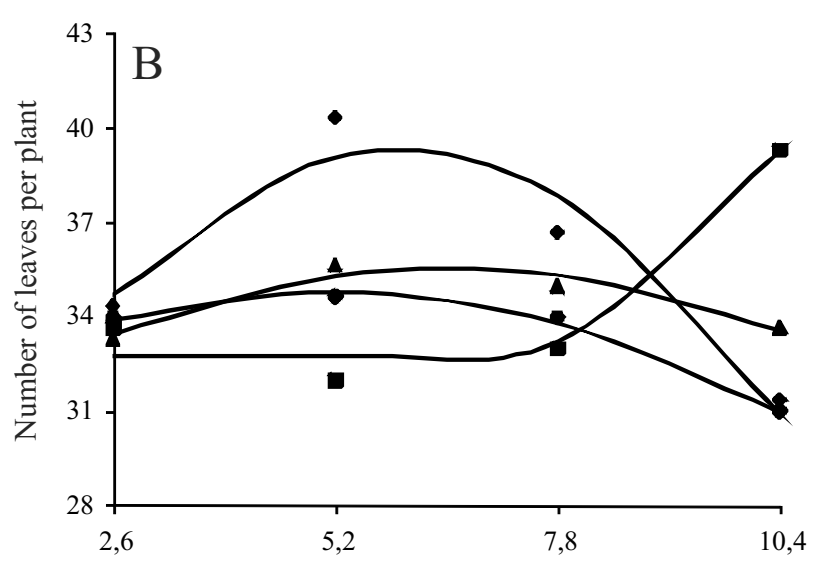

Amounts of scarlet starglory $\left(\mathrm{t} \mathrm{ha}^{-1}\right)$

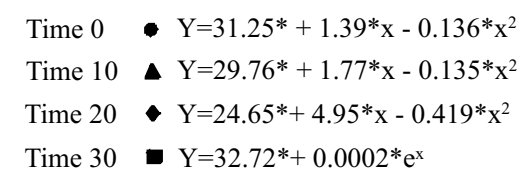

$\mathrm{R}^{2}=0.99 * *$

$\mathrm{R}^{2}=0.92 *$

$\mathrm{R}^{2}=0.92^{*}$

$\mathrm{R}^{2}=0.86^{*}$

Figure 2 - Plant diameter (A) and number of leaves per plant of lettuce (B) under different amounts and times of decomposition of scarlet starglory

in function of the increasing amounts of scarlet starglory applied was observed until the values of $15.33 \mathrm{t} \mathrm{ha}^{-1}$ and $1.41 \mathrm{t} \mathrm{ha}^{-1}$, corresponding to the amounts of incorporated scarlet starglory of $6.68 \mathrm{tha}^{-1}$ and $7.76 \mathrm{tha}^{-1}$, respectively were reached, decreasing thereafter until the maximum amount of scarlet starglory applied of $10.4 \mathrm{t} \mathrm{ha}^{-1}$ (FIG. 3A; FIG. 3C).

Moreover, an upward curve and a quadratic function for fresh and dry mass of lettuce shoots in function of the times of scarlet starglory decomposition (FIG. 3B; FIG. 3D) were adjusted. An increase in the fresh mass of lettuce shoots due to the increase in the time of decomposition was observed, reaching the maximum value of $16.66 \mathrm{t} \mathrm{ha}^{-1}$ in the time 30 days, and representing an increase of $27.7 \%$ in relation the time zero day (FIG. 3B). With the increase in the time of decomposition, there was an increase in the dry mass of lettuce shoots until the value of $1.41 \mathrm{t} \mathrm{ha}^{-1}$, corresponding to the time of 21.4 days, and decreasing thereafter until the time of 30 days (FIG. 3D). These results of increased fresh and dry mass in the times of 30 and 21.4 days, respectively, was due to slow decomposition of dry scarlet starglory due to a high $\mathrm{C} / \mathrm{N}$ ratio. This may have caused a synchrony between the period of greatest demand for nutrients by lettuce and the release of nutrients by scarlet starglory. According to Katayama (1993), the highest nutrient demand in the lettuce crop was in the last weeks of the cycle. According to Silva, Maia and Oliveira (2000), susceptibility to mineralization of organic material proved essential to ensure that the stages of the greatest nutrient demand of the culture were synchronized with the release of nutrients mineralized by the organic fertilizers. Oliveira et al. (2006) also obtained an increase in the average weight of the lettuce head as a function of the increasing concentration of bed-of-poultry applied on dressing. Zárate, Vieira and Cabeças Júnior (1997) also reported increase on the lettuce productivity with increasing amount of bed-of-poultry on dressing.

Oliveira et al. (2006) also obtained an increase in the average weight of the lettuce head as a function of the increasing concentration of bed-of-poultry applied on dressing. Zárate, Vieira and Cabeças Júnior (1997) also reported increase on the lettuce productivity with increasing amount of bed-of-poultry on dressing.

Significant differences between the mean maximum values obtained from the factorial and the control treatment (cattle manure) were observed for the plant height $(\mathrm{PH})$, plant diameter $(\mathrm{PD})$, number of leaves per plant (NL), and fresh (FM) and dry mass (DM) of the lettuce shoots (TAB. 1). These differences were approximately $45.2 \%, 47.9 \%, 21.8 \%, 43.6 \%$ and $13.7 \%$ respectively, confirming the potential of scarlet starglory (spontaneous species) as green manure. 

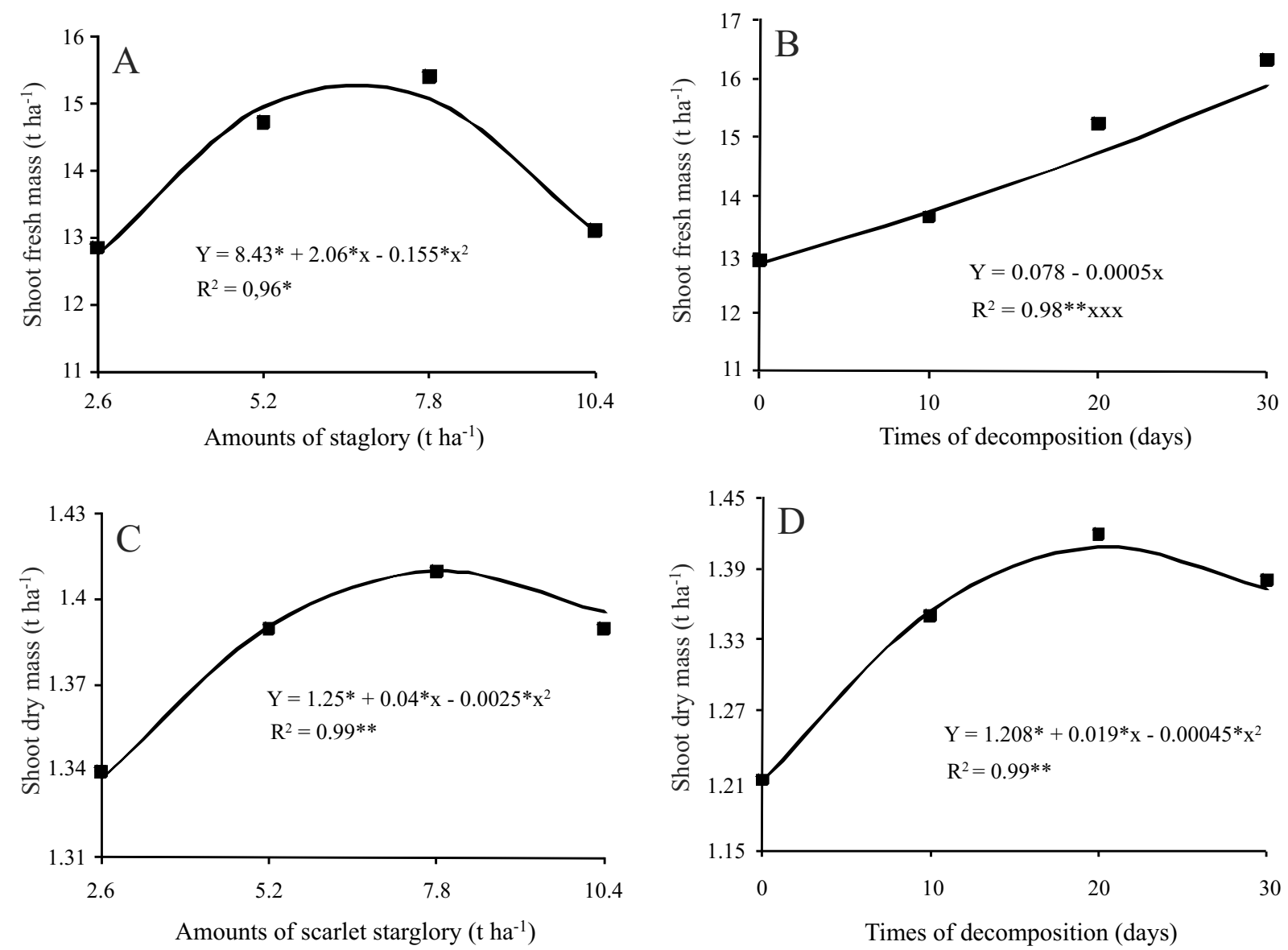

${ }^{*}$ Significant at $\mathrm{p}<0.05$ by $\mathrm{t}$ test

Figure 3 - Shoot fresh (A and B) and dry (C and D) masses of lettuce plants under different amounts and times of decomposition of scarlet starglory

Table 1 - Mean values of plant height (PH), plant diameter (PD), number of leaves per plant (NL), fresh (FM) and dry mass $(\mathrm{DM})$ of lettuce shoots in the treatment with the maximum average in the factorial (amounts $\mathrm{x}$ times) and in the control treatment (with cattle manure)

\begin{tabular}{cccccc}
\hline $\begin{array}{c}\text { Factorial } \\
\text { x control } \\
\text { contrast }\end{array}$ & $\begin{array}{c}\text { PH } \\
\mathrm{cm}\end{array}$ & $\begin{array}{c}\mathrm{PD} \\
\mathrm{cm}\end{array}$ & $\mathrm{NL}$ & $\begin{array}{c}\mathrm{FM} \\
\mathrm{t} \mathrm{ha}^{-1}\end{array}$ & $\begin{array}{c}\mathrm{DM} \\
\mathrm{t} \mathrm{ha}^{-1}\end{array}$ \\
\hline $\begin{array}{c}\text { Maximum } \\
\text { average } \\
\text { value of the } \\
\text { factorial } \\
\text { (amounts } \mathrm{x} \\
\text { times) }\end{array}$ & +23.63 & +25.40 & +39 & +16.76 & +1.41 \\
$\begin{array}{c}\text { Cattle manure } \\
\text { (control) }\end{array}$ & 16.27 & 17.17 & 32 & 11.67 & 1.24 \\
\hline
\end{tabular}

${ }^{+}$Maximum average value of the factorial significantly different from the average of the cattle manure (control); by t test at $5 \%$ significance

\section{Conclusions}

1. The incorporation of dry scarlet starglory into the soil influenced the productive performance of lettuce in a positive way, thereby showing promise for use as a green manure;

2. The highest productivity of the lettuce $\left(15.33 \mathrm{tha}^{-1}\right)$ was obtained with the incorporation of $6.68 \mathrm{t} \mathrm{ha}^{-1}$ of dry scarlet starglory to the ground in time of 30 days before transplanting of the lettuce.

\section{References}

ALCÂNTARA, F. A. et al. Adubação verde na recuperação da fertilidade de um latossolo vermelho-escuro degradado. Pesquisa Agropecuária Brasileira, v. 35, n. 02, p. 277-288, 2000. 
ALVARENGA, M. A. R. et al. Crescimento, teor e acúmulo de macronutrientes em alface americana sob doses de $\mathrm{N}$ aplicadas no solo e de níveis de cálcio aplicados via foliar. Horticultura Brasileira, v. 18, suplemento, p. 803-804, 2000

CAETANO, L. C. S. et al. A cultura da alface: perspectivas, tecnologias e viabilidade. Niterói: PESAGRO-RIO, 2001. 23 p. (Documentos, 78).

CASTILHOS, D. D. et al. Alterações químicas no solo e produção de alface decorrentes da adição de vermicompostos. Magistra, v. 19, n. 02, p. 143-149, 2007.

FAVERO, C.; JUCKSCH, I. Daninhas ou companheiras?. Boletim Informativo da Sociedade Brasileira de Ciência do Solo, v. 25, n. 02, p. 26-27, 2000.

FERREIRA, D. F. Sistema SISVAR para análises estatísticas: manual de orientação. Lavras: Universidade Federal de Lavras, 2000. 37 p.

FILGUEIRA, F. A. R. Novo manual de olericultura: agrotecnologia moderna na produção e comercialização de hortaliças. Viçosa: UFV, 2000. 402 p.

FONTANETTI, A. Adubação verde no controle de plantas invasoras e na produção de alface americana e de repolho. 2003. 64 f. Dissertação (Mestrado) - Universidade Federal de Lavras, Lavras, 2003.

FONTANETTI, A. et al. Adubação verde na produção de alface americana e repolho. Horticultura Brasileira, v. 24, n. 02, p. 146-150, 2006.

JANDEL SCIENTIFIC. Table Curve: curve fitting software. Corte Madeira, 1991. $280 \mathrm{p}$.

KATAYAMA, M. Nutrição e adubação de alface, chicória e almeirão. In: SIMPÓSIO SOBRE NUTRIÇÃO E ADUBAÇÃO DE HORTALIÇAS, 1., 1993, Piracicaba. Anais... Piracicaba: POTAFOS, 1993. p. 141-148.

KLEIN, V. L. G.; AMARAL, F. C. S. Plantas daninhas aquáticas flutuantes. Informe Agropecuário, v. 13, n. 150, p. $35-43,1988$.

LINHARES, P. C. F. et al. Produção de fitomassa de Merremia aegyptia L. em diferentes estádios fenológicos para adubação verde. In: Congresso Brasileiro de Ciência do Solo, 31., 2007, Gramado. Resumos... Gramado: SBCS, 2007.

LINHARES, P. C. F. et al. Avaliação da decomposição da jitirana em cobertura no desempenho agronômico de rúcula. Revista Caatinga, v. 22, n. 03, p. 71-76, 2009a.

LINHARES, P. C. F. et al. Produção de rúcula em função de diferentes tempos de decomposição de salsa. Revista Caatinga, v. 22 , n. 02 , p. $200-205,2009$ b.

LINHARES, P. C. F. et al. Adubação verde com jitirana na produção de rúcula. Revista Caatinga, v. 22, n. 03, p. 215-219, 2009c.

LINHARES, P. C. F. et al. Produção da rúcula em função de diferentes tempos de decomposição da malva veludo. Revista Caatinga, v. 22, n. 02, p. 50-54, 2009d.

LINHARES, P. C. F. et al. Influencia da jitirana em cobertura como adubação verde sobre o desempenho agronômico da alface. Revista Caatinga, v. 22, n. 04, p. 65-69, 2009e.

LOPES, J. C. et al. Produção de alface com doses de lodo de esgoto. Horticultura Brasileira, v. 23, n. 01, p. 143-147, 2005.

OLIVEIRA, M. K. T. et al. Desempenho agronômico da cenoura adubada com jitirana antes de sua semeadura. Revista Ciência Agronômica, v. 42, n. 02, p. 364-372, 2011.

OLIVEIRA, N. G. et al. Plantio direto de alface adubada com "cama" de aviário sobre coberturas vivas de grama e amendoim forrageiro. Horticultura Brasileira, v. 24, n. 01, p. 112-117, 2006.

PORTO, V. C. N. et al. Fontes e doses de matéria orgânica na produção de alface. Revista Caatinga, v. 12, n. 1/2, p. 7-11, 1999.

SAKAMA. Empresa de produção e distribuição de sementes olerícolas. Rio de Janeiro, 2002.

SILVA, F. N.; MAIA, S. S. S.; OLIVEIRA, M. Doses de matéria orgânica na produtividade da cultura da alface em solo Eutrófico da Região de Mossoró, RN. Horticultura Brasileira, v. 18, suplemento, p. 776-777, 2000.

ZÁRATE, N. A. H; VIEIRA, M. C; CABEÇAS JÚNIOR, O. Produção de alface em função de doses e formas de aplicação de cama-de-aviário semi-decomposta. Horticultura Brasileira, v. 15, n. 01, p. 65-67, 1997. 